\title{
The Determinant Factors of E-Commerce Usage Behavior During Flash Sale Program
}

\author{
Arta Moro Sundjaja ${ }^{1 *}$, Gladys Valentina Arisanto ${ }^{2}$, and Sarah Fatimah ${ }^{3}$ \\ ${ }^{1-3}$ Information System Department, School of Information Systems, Bina Nusantara University \\ Jakarta 11480, Indonesia \\ Email: ${ }^{1}$ asundjaja@binus.edu, ${ }^{2}$ gladys_valent@ hotmail.com, ${ }^{3}$ sarah_fatimah90@yahoo.com
}

\begin{abstract}
The research objective is to analyze the determinant factors of the purchase intention during a flash sale program. It is conducted from October 2018 to January 2019. The researchers apply a quantitative approach. The sampling technique is snowball sampling. The survey data are collected from 210 respondents who shop online in Indonesia using questionnaires. The data are examined using Structural Equation Modelling (SEM) with AMOS ver. 25. The research results indicate that the effect of perceived usefulness, information quality, and web quality on purchase intention are mediated by attitude. The flash sale program has a moderating impact on purchase intention. The effect of perceived ease of use and trust in the purchase intention mediated by attitude is not significant. The R-squared value of attitude on e-commerce is 0.527 , and purchase intention is 0.369 . These research results are important for e-commerce management to understand the essential factors of purchase intention during a flash sale program.
\end{abstract}

Index Terms-Purchase Intention, Perceived Ease of Use, Information Quality, Web Quality, Flash Sale Program

\section{INTRODUCTION}

$\mathbf{T}$ ECHNOLOGICAL developments in the age of globalization have brought rapid progress in several areas, including the electronic commerce (ecommerce) industry. The number of internet users in 2017 reached 143.26 million people out of Indonesia's total population of 262 million people [1]. It shows that more than $50 \%$ of Indonesia's population is connected to the Internet. Meanwhile, the population of Indonesia that conducts online commerce transactions is $32.19 \%$ of Internet users. There is a significant increase in Indonesian e-commerce transactions every year. Indonesia's e-commerce transactions reached $\$ 3.5$ billion in 2015, a significant increase of around $\$ 0.9$ billion compared to 2014 [2]. The researchers conclude that with the increasing use of the Internet and e-commerce

Received: July 21, 2020; received in revised form: Sep. 02, 2020; accepted: Sep. 02, 2020; available online: Sep. 22, 2020. *Corresponding Author transactions, the Indonesians' online purchase behavior also increases.

Around 2014, electronic commerce began to develop rapidly in Indonesia. Some e-commerce names like Bhinneka, Lazada, Tokopedia, Blibli, Bukalapak, and others started to advertise a lot through advertising media on TV, the Internet, and others to get people to buy online. The products sold on an e-commerce website are various, such as fashion products, electronic devices, beauty care, household appliances, and transportation tickets.

E-commerce is business, technology, society, and the ability to buy and sell goods and services via the Internet. It involves the process of ordering goods and services, as well as shipping to consumers. Ecommerce was introduced 40 years ago and until now continues to grow with new technology, innovation, and thousands of businesses entering the online market every year. The main goal is to provide comfort, safety, and experience to consumers [3]. In the context of electronics, e-commerce is the production, distribution, marketing, sale, or delivery of goods and services by electronic means [4].

Based on previous research, the concept of flash sale has been analyzed in different industries [5-7]. Flash sale program is a new phenomenon where e-commerce sells various types of products and brands online at a discount for a certain period [5,7]. It has a positive effect on the consumer's purchase intention [8]. It is also made to increase sales of specific products or the sales on the e-commerce website. The main purpose of a flash sale is to sell products in large quantities at a relatively cheap price [5].

Several studies on the determinant factors of purchase intention on the marketplace have been conducted at Indonesia [6, 9], Malaysia [10], Dubai [11], Brazil [8, 12], India [5, 7, 13], Spain [14], Slovenia [15], and USA [16]. Research on the factors that influence purchase intention has been carried out in the e-commerce industry [7, 9, 10, 13], food retail [17], and online hotel [16]. The previous study has in- 
Cite this article as: A. M. Sundjaja, G. V. Arisanto, and S. Fatimah, "The Determinant Factors of E-Commerce Usage Behavior During Flash Sale Program", CommIT (Communication \& Information Technology) Journal 14(2), 65-72, 2020.

vestigated that trust, risk, and perceived usefulness influence consumer interest in $\mathrm{C} 2 \mathrm{C}$ e-commerce [9]. The other study evaluates a new model that combines website quality aspects with other trust-building factors [10]. Another study looks at the characteristics of e-commerce websites (information quality, website features, and product factors) that influence purchase intentions of food products [17]. The latest research in model building analyzes the impact of flash sale program on purchase intentions and the moderate impact of attractiveness on the relationship between intention to purchase discounted and impulsive products, hedonic perceptions, and financial risk [8].

Then, perceived ease of use refers to the degree to which the user claims to believe that using a specific system will be simple and easy. It has a positive and significant relationship to attitude [18]. Online shopping makes it easy to compare products among vendors. This condition positively affects the relationship between perceived ease of use and attitude on online shopping. The first hypothesis is as follows.

H1: there is a positive effect between perceived ease of use and attitude.

Perceived usefulness is the extent to which consumers believe that using certain technologies will improve work performance in an organizational context. Perceived usefulness has a positive and significant effect on attitude because the perceived benefits such as offering various products will bring a positive attitude to online shopping [18]. Thus, the second hypothesis is:

$\mathrm{H} 2$ : there is a positive effect between perceived usefulness and attitude.

Trust is an essential factor in influencing online purchases and increase consumers to buy a product in e-commerce. It is also a means to influence the decisions of online consumers [10, 14, 19]. Previous research shows a positive and significant effect of trust on the attitude of buying airline tickets [20]. Another study also shows a positive and significant impact of trust on attitude in the use of Instagram [21]. In the context of $\mathrm{B} 2 \mathrm{C}$ e-commerce, trust is a key antecedent in determining online purchase intentions through behavioral attitude [22]. The third hypothesis is as follows.

H3: there is a positive effect between trust and attitude.
Information quality is the quality of information presented to help consumers. Information quality allows consumers to find a product and increase the satisfaction of the selected product [17]. Previous research has also shown that the information quality is positive and significant on attitude in online shopping [23]. So, the fourth hypothesis is:

H4: there is a positive effect between information quality and attitude.

Web quality is an essential factor in ecommerce [16]. Website quality is determined by system quality, service quality, and information quality [24]. A good website has an interactive design to accommodate consumers' interaction and attractive appearance to attract consumers to purchase the product. The previous research has found a positive and significant relationship between web quality and attitude toward the web $[25,26]$. The fifth hypothesis is:

H5: there is a positive effect between web quality and attitude.

Purchase intention is defined as a measure of consumer desire to make online purchases in ecommerce [13]. In e-commerce, it is the relationship between intention and behavior [27]. Attitude results from consumers' trust in the positive or negative online shopping experience [13]. In previous ecommerce studies, attitude towards e-commerce has been studied as one of the main factors of online consumer behavior [28]. The attitude of consumers to act will determine the decision. Thus, purchase intention is a factor that predicts the consumer's decision to make a transaction. Therefore, the sixth hypothesis is as follows.

H6: there is a positive effect between attitude and purchase intention.

Based on previous research, a flash sale is a new phenomenon where e-commerce sells various products and brands online with discount in a specified period $[5,6]$. Flash sale program has a positive effect on consumers' purchase intentions [8]. So, the last hypothesis is:

H7: Flash sale program moderates the relationship between attitude and purchase intention.

The researchers conclude that previous researchers have not examined the determinant factors of purchase 
Cite this article as: A. M. Sundjaja, G. V. Arisanto, and S. Fatimah, "The Determinant Factors of E-Commerce Usage Behavior During Flash Sale Program", CommIT (Communication \& Information Technology) Journal 14(2), 65-72, 2020.

intention during a flash sale program. The research also investigates the moderation effect of the flash sale program. The flash sale is first researched in India during the celebration of the Big Day [5]. Therefore, the research purpose is to examine the effect of perceived ease of use, perceived usefulness, trust, information quality, and web quality on purchase intention mediated by attitude and the moderating effect of flash sale program on the purchase intention.

\section{Research Method}

The research applies a quantitative approach based on the philosophy of positivism to examine the relationship between variables. The method of analysis uses Structural Equation Modelling (SEM) with AMOS ver. $25[13,29]$. The research uses descriptive and explanatory methods. Descriptive research illustrates or describes each of the research variables. Meanwhile, explanatory research explains the causal relationship (cause-effect) among research variables. The research is conducted from October 2018 to January 2019.

In the research, sample determination is based on the target population of consumers who have purchased online at e-commerce in Indonesia. The components of population are limitless and are not known for sure. Besides, there are no members of the population. The complexity of population objects is also heterogeneous that the elements of the population have relatively different characteristics from one to another.

The used sampling technique is snowball sampling. This technique is chosen to provide the best results to represent the population. Researchers will randomly select e-commerce and online shopping community groups on social media to distribute questionnaires. The subjects of the research are the followers of ecommerce social media in Indonesia. The researchers believe that someone who decides to follow social media of e-commerce has an interest or concern in online shopping in Indonesia. There are several sample selection criteria. First, the respondents have ever purchased online at e-commerce in Indonesia. Second, the age of respondents is a minimum of 13 years old. Third, the respondents' geographical location (domicile or location of work) is in Indonesia. They are also asked to choose the top three e-commerce sites used [30]. Hence, the number of samples in the study is 210 respondents.

Data collection techniques are collective administration, electronic questionnaires, and administration in public spaces. The researchers make an electronic questionnaire using Google Forms, and the research survey is conducted from December 2018 to January

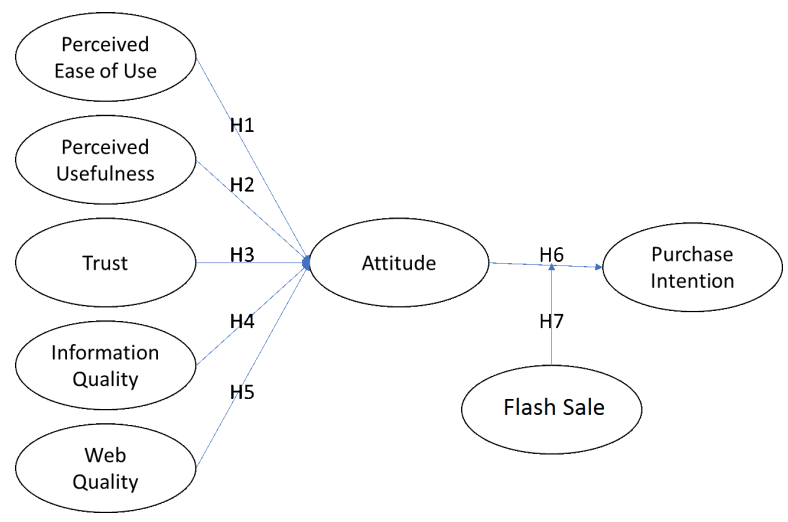

Fig. 1. Conceptual research model.

2019 through social media such as Instagram, Facebook, WhatsApp, and Line. Researchers frequently send invitations to prospective respondents online to fill out the questionnaire. Although the distribution through social media has a low response rate, researchers find respondents who fit the criteria through online distribution.

Researchers compile all indicators in the research by adopting indicators that discuss the influencing factors on purchase intention during the flash sale program in e-commerce. Indicators in the research outside of Indonesia using English will be translated first to identify ambiguous questions. Thus, the respondents understand the question well. Indicators of perceived ease of use and perceived usefulness are adapted from Ref. [9]. Indicators of purchase intention, trust, information quality, and web quality are from Ref. [10]. Then, the indicators of attitude are from Ref. [13]. Figure 1 shows the conceptual research model.

\section{Results AND DisCUSSION}

Based on gender, $59 \%$ or 123 respondents are female, and $41 \%$ or 87 respondents are male. For the age, most of the respondents are 21 to 30 years old (59\% or 123 respondents). There are also 54 respondents aged 13 to 20 years (26\%), 20 respondents aged 31 to 40 years $(9 \%)$, and 13 respondents aged over 40 years $(6 \%)$. Then, $3 \%$ or 5 respondents have a junior high school education level. About 54\% or 114 respondents have a high school or vocational education level. There are 58 respondents with diploma/bachelor's degrees (27\%), 24 respondents with master's degrees (12\%), and 9 respondents with a doctoral degree $(4 \%)$. By profession, most of the respondents are students $(57 \%$ or 120 respondents). It is followed by employees (34\% or 70 respondents), entrepreneurs (6\% or 13 respondents), and housewives (3\% or 7 respondents). 
Cite this article as: A. M. Sundjaja, G. V. Arisanto, and S. Fatimah, "The Determinant Factors of E-Commerce Usage Behavior During Flash Sale Program", CommIT (Communication \& Information Technology) Journal 14(2), 65-72, 2020.

TABLE I

Respondent Profile and E-Commerce Purchase Behaviour.

\begin{tabular}{|c|c|c|c|c|c|}
\hline Question & $\mathrm{N}$ & $\%$ & Question & $\mathrm{N}$ & $\%$ \\
\hline Gender & & & E-Commerce Purchase Frequency & & \\
\hline Male & 87 & 41 & $\geq 3$ times/week & 8 & 4 \\
\hline Female & 123 & 59 & $<3$ times/week & 51 & 24 \\
\hline Age & & & $<3$ times/month & 71 & 34 \\
\hline $13-20$ & 54 & 26 & $\geq 3$ times/month & 42 & 20 \\
\hline $21-30$ & 123 & 59 & $\overline{\geq} 3$ times/year & 19 & 9 \\
\hline $31-40$ & 20 & 9 & $<3$ times/year & 19 & 9 \\
\hline$>40$ & 13 & 6 & E-Commerce Purchase Value & & \\
\hline Education & & & $<\operatorname{Rp} 100,000.00$ & 16 & 8 \\
\hline Junior High School & 5 & 3 & $<\mathrm{Rp} 450,000.00$ & 144 & 68 \\
\hline Senior High School & 114 & 54 & $<\mathrm{Rp} 1,000,000.00$ & 37 & 18 \\
\hline Diploma/Undergraduate & 58 & 27 & $\geq \mathrm{Rp} 1,000,000.00$ & 13 & 6 \\
\hline Master Degree & 24 & 12 & E-Commerce Platform & & \\
\hline Doctoral Degree & 9 & 4 & Tokopedia & 180 & 85.7 \\
\hline Occupation & & & Shopee & 171 & 81.4 \\
\hline Student & 120 & 57 & Lazada & 128 & 60.9 \\
\hline Housewife & 7 & 3 & Bukalapak & 79 & 37.6 \\
\hline Entrepreneur & 13 & 6 & JD.id & 36 & 17.1 \\
\hline Employee & 70 & 34 & Blibli.com & 21 & 10 \\
\hline
\end{tabular}

TABLE II

The Results of Missing Value Test, Normality Test, Validity, and Reliability Tests.

\begin{tabular}{|c|c|c|c|c|c|c|c|}
\hline \multirow{2}{*}{ Variables } & \multirow{2}{*}{ Missing Value } & \multicolumn{2}{|c|}{ Skewness } & \multicolumn{2}{|c|}{ Kurtosis } & \multicolumn{2}{|c|}{ Validity and Reliability } \\
\hline & & Statistic & Std. Error & Statistic & Std. Error & r-calculate & $\alpha$ \\
\hline Purchase intention & 0 & -0.329 & 0.168 & 0.490 & 0.334 & 0.665 & \\
\hline Perceived ease of use & 0 & -0.535 & 0.168 & -0.079 & 0.334 & 0.742 & \\
\hline Perceived usefulness & 0 & -0.685 & 0.168 & 0.226 & 0.334 & 0.659 & \\
\hline Trust & 0 & 0.075 & 0.168 & -0.436 & 0.334 & 0.677 & 0.937 \\
\hline Information quality & 0 & -0.259 & 0.168 & 0.149 & 0.334 & 0.839 & \\
\hline Web quality & 0 & 0.064 & 0.168 & -0.335 & 0.334 & 0.853 & \\
\hline Attitude & 0 & -0.266 & 0.168 & -0.452 & 0.334 & 0.811 & \\
\hline
\end{tabular}

Based on the frequency of shopping on e-commerce sites, most respondents shop less than 3 times per month (34\% or 71 respondents). The results are followed by more than or equal to 3 times per month ( $20 \%$ or 42 respondents), less than 3 times per week ( $24 \%$ or 51 respondents), less than 3 times per month (9\% or 19 respondents), more than or equal to 3 times per year (9\% or 19 respondents), and more than or equal to 3 times per week (4\% or 8 respondents). For the spending on e-commerce sites, 16 respondents have spent less than Rp100,000.00 on e-commerce sites (8\%). Then, 144 respondents spend less than Rp450,000.00 (68\%), and 37 respondents use less than Rp1,000,000.00 (18\%) on e-commerce sites. About $6 \%$ or 13 respondents have average spending of more than or equal to Rp1,000,000.00. According to the most commonly used e-commerce, the top three ecommerces are Tokopedia (85.7\%), Shopee (81.4\%), and Lazada $(60.9 \%)$. In this question, the respondents can choose three answers. Table I presents the profile and behavior of respondents who shop through ecommerce during the flash sale program.

The researchers conduct the missing value test. It examines the incomplete data from the data collection process. Based on the filled questionnaire results, the data are complete because the questionnaire designed using Google Forms has added the function of the validation field that must not be empty. Next, the researchers test the normality to determine whether the data are normally distributed or not. Research using questionnaires can be tested parametrically to analyze consumers' opinions using a Likert scale. The sample used in the research is below 300 so that normality tests can be done by evaluating the distribution of skewness and kurtosis [31]. Table II shows the skewness and kurtosis value of all variables. If the $\mathrm{z}$-score has a range outside of -3.29 and +3.29 with an alpha level of 0.05 , the data distribution is considered abnormal. 
Cite this article as: A. M. Sundjaja, G. V. Arisanto, and S. Fatimah, "The Determinant Factors of E-Commerce Usage Behavior During Flash Sale Program", CommIT (Communication \& Information Technology) Journal 14(2), 65-72, 2020.

TABLE III

DESCRIPTIVE ANALYSIS AND CONFIRMATORY FACTORS ANALYSIS RESUlTS OF QUESTIONNAIRE INDICATORS.

\begin{tabular}{|c|c|c|c|c|}
\hline Variables & Mean & Standardized Loadings & $\mathrm{AVE}^{\mathrm{a}}$ & $\mathrm{CR}^{\mathrm{a}}$ \\
\hline \multicolumn{5}{|l|}{ Perceived ease of use: 4.18} \\
\hline Easy to use e-commerce website & 4.22 & 0.881 & \multirow{3}{*}{0.742} & \multirow{3}{*}{0.896} \\
\hline Easy to learn e-commerce websites & 4.21 & 0.871 & & \\
\hline Easy to find the required product or item & 4.10 & 0.833 & & \\
\hline \multicolumn{5}{|l|}{ Perceived usefulness: 4.17} \\
\hline Improve performance in finding and buying products on e-commerce websites & 4.18 & 0.854 & \multirow{3}{*}{0.734} & \multirow{3}{*}{0.891} \\
\hline Increase effectiveness in finding and buying products on e-commerce websites & 4.19 & 0.942 & & \\
\hline Content on Indonesian e-commerce websites is useful. & 4.14 & 0.766 & & \\
\hline \multicolumn{5}{|l|}{ Trust: 3.44} \\
\hline $\begin{array}{l}\text { Convince consumers about the products on e-commerce websites during the flash } \\
\text { sale program }\end{array}$ & 3.51 & 0.870 & \multirow[t]{3}{*}{0.724} & \multirow[t]{3}{*}{0.886} \\
\hline Trust in products on e-commerce websites during the flash sale program & 3.40 & 0.934 & & \\
\hline Flash sale programs on e-commerce in Indonesia can be trusted & 3.40 & 0.737 & & \\
\hline \multicolumn{5}{|l|}{ Information quality: 3.80} \\
\hline Provide accurate information & 3.90 & 0.880 & \multirow{3}{*}{0.738} & \multirow{3}{*}{0.894} \\
\hline Provide the needed information & 3.68 & 0.840 & & \\
\hline Present the latest information & 3.83 & 0.858 & & \\
\hline \multicolumn{5}{|l|}{ Web quality: 3.77} \\
\hline Website features are good & 3.82 & 0.848 & \multirow{3}{*}{0.712} & \multirow{3}{*}{0.881} \\
\hline The quality of the website meets the expectations & 3.82 & 0.869 & & \\
\hline The website offers unique features & 3.68 & 0.814 & & \\
\hline \multicolumn{5}{|l|}{ Attitude on e-commerce: 3.99} \\
\hline Shopping on e-commerce is a good idea & 3.99 & 0.817 & \multirow{3}{*}{0.669} & \multirow{3}{*}{0.858} \\
\hline Shopping on e-commerce is fun & 4.00 & 0.858 & & \\
\hline Think positive about e-commerce & 3.99 & 0.777 & & \\
\hline \multicolumn{5}{|l|}{ Purchase intention on e-commerce: 3.55} \\
\hline Purchase intention of product that is recommended by the e-commerce & 3.69 & 0.753 & \multirow{3}{*}{0.592} & \multirow{3}{*}{0.811} \\
\hline High purchase intention of product that is recommended by the e-commerce & 3.44 & 0.867 & & \\
\hline Purchase intention of product that is recommended by e-commerce in the future & 3.53 & 0.677 & & \\
\hline
\end{tabular}

TABLE IV

Modification Indices And Par Change Value.

\begin{tabular}{lrr}
\hline Covariance & M.I & Par Change \\
\hline $\begin{array}{l}\text { E1 (PEOU 1) - E2 } \\
\text { (PEOU 2) }\end{array}$ & 4.067 & 0.022 \\
$\begin{array}{l}\text { E4 (PU 1) - E6 (PU } \\
\text { 3) }\end{array}$ & 6.859 & -0.042 \\
$\begin{array}{l}\text { E16 (ATT 1) - E18 } \\
\text { (ATT 3) }\end{array}$ & 8.910 & -0.058 \\
\hline M.I= modification indices &
\end{tabular}

The researchers can conclude that the data are normally distributed.

For the pre-test, the questionnaires are distributed to 30 respondents. The results of the questionnaire are examined using SPPS. Using Bivariate Correlation, researchers test the validity of all indicators in each variable. Moreover, the researchers calculate Cronbach's alpha by using SPPS to test the reliability of the research instrument. Reliability for each factor is calculated using the coefficient of $\alpha$, with a value of 0.937 [13]. Based on Table II, the data are valid and reliable.

Then, Table III shows the mean, standardized loading, average variance extracted, and construct reliability of each indicator and variable. In the research, the cut-off value is 0.6 for factor analysis and 0.5 for the average variance extracted. Therefore, the indicators already accurately measure the perceived ease of use, perceived usefulness, trust, information quality, web quality, attitude, and purchase intention on ecommerce. For testing the reliability, the cut-off value for construct reliability is 0.8 . All variables have CR values above 0.8 , so that the variables are reliable.

Next, the researchers investigate the measurement model using the goodness-of-fit indices. The results of goodness-of-fit indices show the model is fairly fit: $\chi^{2}=229.346, \chi^{2} /$ d.f $=1.365 ;$ GFI $=0.910 ;$ AGFI $=$ 0.876; NFI $=0.930$; CFI $=0.980 ;$ RMSEA $=0.042$; and TLI $=0.975$. The researchers refine the model using modification indices by adding three correlations between indicators of perceived ease of use (PEOU) 1 and 2, indicators of perceived usefulness (PU) 1 and 3 , and indicators of attitude (ATT) 1 and 3. Table IV 


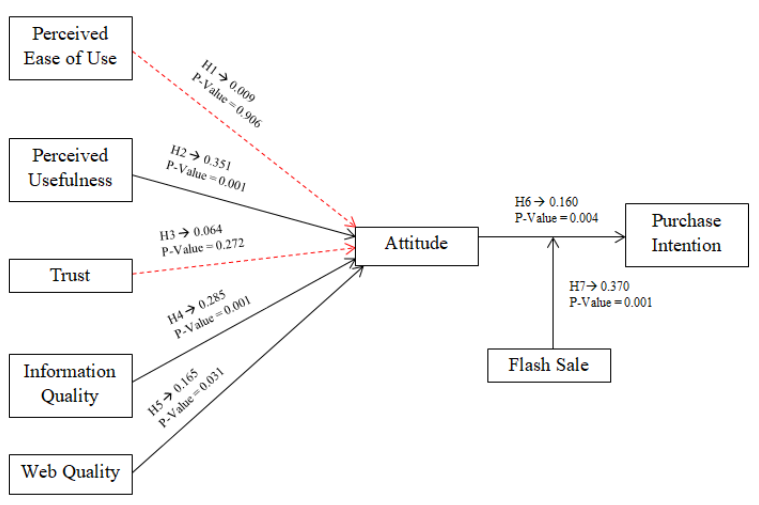

Fig. 2. Path analysis results.

shows the modification indices and par change value from three variables. After the modification of model, the goodness-of-fit indices increase and show good fit: $\chi^{2}=184.145, \chi^{2} /$ d.f $=1.116 ;$ GFI $=0.925 ;$ AGFI $=$ $0.900 ; \mathrm{NFI}=0.944 ; \mathrm{CFI}=0.994 ;$ RMSEA $=0.024$; and TLI $=0.992$. The final model also demonstrates good understanding of the purchase intention on e-commerce during the flash sale program.

Figure 2 shows the path coefficients and p-value for all hypotheses. Five paths are significant, and two paths are insignificant. The perceived usefulness affects the attitude toward e-commerce (H2). This finding supports the previous study that there is a positive influence between perceived usefulness and attitude toward e-commerce [18, 32, 33]. Similarly, the information quality has an effect on the attitude toward e-commerce (H4). This finding is in line with the previous study. There is a positive influence between information quality and attitude toward e-commerce [23, 25, 26].

Moreover, web quality influences the attitude toward e-commerce (H5). The previous study also finds a significant and positive influence between website quality and attitude toward e-commerce [25, 26]. Then, the attitude toward e-commerce also affects purchase intention (H6). This result is in accordance with the previous study [13, 18, 28].

Meanwhile, the perceived ease of use does not affect the attitude toward e-commerce (H1). This finding does not support the previous finding. References [32, 33] suggest a significant and positive influence between perceived ease of use and the attitude toward ecommerce. Similarly, the trust does not influence the attitude toward e-commerce (H3). This result is different from the previous study that finds a significant and positive influence between trust and the attitude toward e-commerce [20-22]. The researchers suspect that the group of young respondents have no difficulty in using and trusting the e-commerce.
The research model suggests that flash sale program increases the purchase intention (H7). The finding also shows that the moderating effect is strong. The path coefficient of a flash sale program is 0.370 . Flash sale program provides a more substantial impact in improving attitudes in making decisions to buy products in e-commerce. The research offers a new perspective compared to previous research [5]. It highlights the importance of considering the perceived usefulness, information quality, and web quality in forming a positive attitude toward e-commerce that will increase purchase intention $[25,26]$. The R-squared value of attitude toward e-commerce is 0.527 . It means $52.7 \%$ of the attitude toward e-commerce can be explained by perceived ease of use, perceived usefulness, trust, information quality, and web quality. Meanwhile, the $\mathrm{R}$-squared of purchase intention on e-commerce is 0.369 . It implies that $36.9 \%$ of the purchase intention on e-commerce can be explained by attitude toward e-commerce and the flash sale program.

The research implication is that the seller should provide more accurate information, updated stock information, and detailed product description to increase the information quality [17]. Furthermore, The ecommerce developer should improve the user experience in searching and buying products to increase the perceived usefulness [34]. The e-commerce developer should also embed artificial intelligence and big data to enhance the product recommendation to improve the user experience [35]. The contribution of the findings to the Technology Acceptance Model is that the perceived usefulness, information quality, and web quality affect the purchase intention during the flash sale program.

\section{CONCLUSiON}

The results show that the perceived usefulness, information quality, and web quality affect the purchase intention of e-commerce mediated by attitude toward e-commerce. The flash sale program increases the purchase intention of e-commerce. Another interesting finding is that the perceived ease of use and trust do not affect the attitude toward e-commerce. The R-squared of attitude toward e-commerce and purchase intention on e-commerce is $52.7 \%$ and $36.9 \%$.

Despite the interesting implication on the moderating effect of the flash sale program on the purchase intention, the research has several limitations. First, the respondents' age is in the range of 21-30 years. They are already familiar with e-commerce technology. These respondents likely differ from older consumers. Therefore, future researchers should replicate the proposed model using different age range. Second, the 
Cite this article as: A. M. Sundjaja, G. V. Arisanto, and S. Fatimah, "The Determinant Factors of E-Commerce Usage Behavior During Flash Sale Program”, CommIT (Communication \& Information Technology) Journal 14(2), 65-72, 2020.

researchers focus on the positive impact of the flash sale program on purchase intention. Future researchers should investigate the effect on consumers' experience or satisfaction. Third, the participants are not asked to mention their living location. Since Indonesia is a multicultural country, it is interesting to test the moderating effect on cultural identity on purchase intention. Fourth, the research does not accommodate other determinant variables, such as risk, gamification, or social media marketing. Future researchers should explore those variables to achieve a better understanding of purchase behavior in e-commerce.

\section{REFERENCES}

[1] Asosiasi Penyelenggara Jasa Internet Indonesia. (2017) Hasil survei penetrasi dan perilaku pengguna Internet Indonesia 2017. [Online]. Available: https://www.apjii.or.id/survei

[2] Databoks. (2017) 2011-2015, nilai transaksi e-commerce Indonesia melonjak 250 persen. [Online]. Available: https://bit.ly/2FJBHVE

[3] C. Dan, "Electronic commerce: State-of-the-art," American Journal of Intelligent Systems, vol. 4, no. 4, pp. 135-141, 2014.

[4] World Trade Organization. (2018) Electronic commerce. [Online]. Available: https://www.wto.org/english/thewto_e/ minist_e/mc11_e/briefing_notes_e/bfecom_e.htm

[5] S. Agrawal and S. Abhinav Sareen, "Flash salesThe game changer in Indian e-commerce industry," International Journal of Advance Research and Innovation, vol. 4, no. 1, pp. 192-195, 2016.

[6] E. B. Prasetyo and F. Zen, "The effect of discount price on purchasing intentions through consumer's perceived risk in the flash sale program at shopee," in $4^{\text {th }}$ Padang International Conference on Education, Economics, Business and Accounting (PICEEBA-2 2019). West Sumatera, Indonesia: Atlantis Press, Nov. 16-17, 2020, pp. 633-643.

[7] K. A. Vakeel, K. Sivakumar, K. Jayasimha, and S. Dey, "Service failures after online flash sales: Role of deal proneness, attribution, and emotion," Journal of Service Management, vol. 29, no. 2, pp. 253-276, 2018.

[8] F. D. O. Santini, C. H. Sampaio, M. G. Perin, and V. A. Vieira, "An analysis of the influence of discount sales promotion in consumer buying intent and the moderating effects of attractiveness," Revista de Administração (São Paulo), vol. 50, no. 4, pp. 416-431, 2015.

[9] M. Dachyar and L. Banjarnahor, "Factors influencing purchase intention towards consumer- to-consumer e-commerce," Intangible Capital, vol. 13, no. 5, pp. 946-966, 2017.

[10] M. Nilashi, D. Jannach, O. Bin Ibrahim, M. D. Esfahani, and H. Ahmadi, "Recommendation quality, transparency, and website quality for trust-Building in recommendation agents," Electronic Commerce Research and Applications, vol. 19, pp. 70-84, 2016.

[11] M. R. Alam, M. A. Faiz, and M. Z. Aftab, "Mobile marketing: A study of buying intention," Journal of Economics, Management and Trade, vol. 7, no. 3, pp. 218-226, 2015.

[12] S. Bebber, G. S. Milan, D. De Toni, L. Eberle, and L. A. Slongo, "Antecedents of purchase intention in the online context," Journal of Relationship Marketing, vol. 16, no. 1, pp. 82-98, 2017.

[13] S. Singh and S. Srivastava, "Moderating effect of product type on online shopping behaviour and purchase intention: An Indian perspective," Cogent Arts \& Humanities, vol. 5, no. 1, pp. 127, 2018.

[14] T. Escobar-Rodríguez and R. Bonsón-Fernández, "Analysing online purchase intention in Spain: Fashion e-commerce," Information Systems and E-Business Management, vol. 15, no. 3, pp. 599622, 2017.

[15] G. Jordan, R. Leskovar, and M. Marič, "Impact of fear of identity theft and perceived risk on online purchase intention," Organizacija, vol. 51, no. 2, pp. 146-155, 2018.

[16] F. Ali, "Hotel website quality, perceived flow, customer satisfaction and purchase intention," Journal of Hospitality and Tourism Technology, vol. 7, no. 2, pp. 213-228, 2016.

[17] N. A. Rozekhi, S. Hussin, and A. M. Noor, "Attributable e-commerce toward purchase intention: Osnline search of food product," The SIJ Transactions on Industrial, Financial \& Business Management (IFBM), vol. 2, no. 3, pp. 128-134, 2014.

[18] Juniwati, "Influence of perceived usefulness, ease of use, risk on attitude and intention to shop online," European Journal of Business and Management, vol. 6, no. 27, pp. 218-229, 2014.

[19] N. Laura, "The effect of trust and service quality toward patient satisfaction with customer value as intervening variable," Binus Business Review, vol. 7, no. 2, pp. 157-162, 2016.

[20] Renny, S. Guritno, and H. Siringoringo, "Perceived usefulness, ease of use, and attitude towards online shopping usefulness towards online airlines ticket purchase," Procedia-Social and Behavioral Sciences, vol. 81, pp. 212-216, 2013. 
[21] R. K. Ekawati, "Peran mediasi sikap atas pengaruh kepercayaan terhadap niat menggunakan Instagram," Jurnal JuSiTik (Jurnal Sistem Informasi dan Teknologi Informasi Komunikasi), vol. 1, no. 1, pp. 23-32, 2017.

[22] N. Hongyao, "Online purchase intention in B2C e-commerce: An empirical study," in The Twelfth Wuhan International Conference on E-Business, Wuhan, China, May 25-26, 2013, pp. 482-489.

[23] J. V. Chen, D. Rungruengsamrit, T. Rajkumar, and D. C. Yen, "Success of electronic commerce web sites: A comparative study in two countries," Information \& Management, vol. 50, no. 6, pp. 344-355, 2013.

[24] E. Supriyati, "Studi empirik social commerce (scommerce) dari sudut pandang kualitas website," Simetris: Jurnal Teknik Mesin, Elektro dan Ilmu Komputer, vol. 6, no. 1, pp. 89-94, 2015.

[25] J. Jiménez-Barreto and S. Campo-Martínez, 'Destination website quality, users' attitudes and the willingness to participate in online co-creation experiences," European Journal of Management and Business Economics, vol. 27, no. 1, pp. 2641, 2018.

[26] A. M. Sundjaja and A. F. Komala, "The determinant factors of the intention to purchase online car insurance," International Journal of Scientific \& Technology Research, vol. 8, no. 7, pp. 511-517, 2019.

[27] D. J. Kim, D. L. Ferrin, and H. R. Rao, "A trust-based consumer decision-making model in electronic commerce: The role of trust, perceived risk, and their antecedents," Decision Support Systems, vol. 44, no. 2, pp. 544-564, 2008.

[28] M. Zendehdel, L. H. Paim, and S. B. Osman, "Students' online purchasing behavior in Malaysia: Understanding online shopping attitude," Cogent Business \& Management, vol. 2, no. 1, pp. 1-13, 2015.

[29] V. Singh and S. K. Sharma, "Analyzing the moderating effects of respondent type and experience on the fuel efficiency improvement in air transport using Structural Equation Modeling," European Transport Research Review, vol. 8, no. 2, pp. 120, 2016.

[30] F. M. Andrews and A. R. Herzog, "The quality of survey data as related to age of respondent," Journal of the American Statistical Association, vol. 81, no. 394, pp. 403-410, 1986.

[31] H. Y. Kim, "Statistical notes for clinical researchers: Assessing normal distribution (2) using skewness and kurtosis," Restorative Dentistry \& Endodontics, vol. 38, no. 1, pp. 52-54, 2013.
[32] D. L. Kasilingam, "Understanding the attitude and intention to use smartphone chatbots for shopping," Technology in Society, vol. 62, no. August, 2020.

[33] M. Rizwan, S. M. Umair, H. M. Bilal, M. Akhtar, and M. Bhatti, "Determinants of customer intentions for online shopping: A study from Pakistan," Journal of Sociological Research, vol. 5, no. 1, pp. 248-272, 2014.

[34] B. C. Shia, M. Chen, A. D. Ramdansyah, and S. Wang, "Comparison of decision making in adopting e-commerce between Indonesia and Chinese Taipei (Case study in Jakarta and Taipei City)," American Journal of Industrial and Business Management, vol. 5, no. 12, pp. 7480-768, 2015.

[35] S. B. Yudhoatmojo and R. Ramadana, "Analysis on gamification features usage on Indonesia ecommerce sites using Octalysis Framework," in The $2^{\text {nd }}$ International HCI and UX Conference in Indonesia, Jakarta, Indonesia, April 13-15, 2016, pp. 1-5. 